\title{
Розробка моделі газотурбінного двигуна на основі даних перерахування характеристик компресора динамічного принципу дії
}

\author{
О. О. Гурський, О. С. Гончаренко, С. М. Дубна $ه$ \\ Одеська національна академія харчових технологій, вул. Канатна, 112, м. Одеса, 65039, Україна \\ $\triangle$ e-mail: dubna_s@ukr.net
}

\begin{abstract}
Метою роботи є підвищення ефективності функиіонування газотурбінного двигуна иляхом використання координувальної системи автоматичного управління. Для досягнення поставленої мети необхідно розробити модель газотурбінного двигуна на базі моделі статичних режимів роботи компресора динамічного принципу діï, що реалізована засобами середовища MATLAB \Simulink. Aктуальність розробки відповідної моделі обумовлена необхідністю оиінки енергоефективності функиіонування газотурбінного двигуна, а також можливістю побудови певної координувальної системи автоматичного управління, щзо використовує відхилення від співвідношення змінних системи при регулюванні технологічних параметрів. Автоматичні системи координувального управління дозволяють узгодити відповідні перехідні процеси і можуть забезпечити ряд позитивних особливостей при функиіонуванні об'єкта управління. У даній роботі представляється розробка елементної моделі газотурбінного двигуна як об'єкта керування. Ця модель розробляється для синтезу різноманітних систем автоматичного управління, що забезпечують узгодження перехідних процесів при регулюванні. Надається структурно-параметрична схема газотурбінного двигуна з описом окремих ї̈ елементів. Відображається принци перетворення вихідної моделі компресора у відповідну модель газотурбінного двигуна. При розробиі математичної моделі, відповідно конструктивним особливостям, газотурбінний двигун розділяється на турбокомпресор, камеру згоряння, турбіну і реактивне сопло. Виходячи з такого поділу, безпосередньо розглядається математичний опис окремих елементів газотурбінного двигуна, а потім зв'язується в єдину математичну схему. У заключній частині роботи наведені результати моделювання. Це статичні характеристики компресора і перехідні характеристики турбіни за швидкістю обертання валу. Приводиться аналіз результатів моделювання на основі порівняння статичних характеристик моделі вихідного компресора і компресора газотурбінного двигуна.
\end{abstract}

Ключові слова: Турбореактивний двигун; Газотурбінний двигун; Математична модель; Характеристики турбокомпресора; Камера згоряння; Турбіна

\author{
doi: https://doi.org/10.15673/ret.v55i2.1362
}

(C) The Author(s) 2019. This article is an open access publication

This work is licensed under the Creative Commons Attribution 4.0 International License (CC BY)

http://creativecommons.org/licenses/by/4.0/

\section{1 Вступ}

Розробка моделі газотурбінного двигуна (ГТД) - необхідний етап як при синтезі системи автоматичного управління, так і при аналізі ефективності функціонування газотурбінної установки. За минуле століття експлуатації газотурбінних установок і реактивних двигунів було виконано досить велика кількість наукових робіт, пов'язаних як із розробкою систем управління даних двигунів, так і з моделюванням і аналізом ефективності іх роботи.

В даний час інтерес до розвитку різних САУ ГТД не зник і пов'язаний він, в першу чергу, з підвищенням якості регулювання технологічних па- раметрів і з підвищенням ефективності функціонування ГТД $[1,2]$. Так, представляються багатоконтурні, логіко-динамічні системи управління ГТД, що функціонують в умовах параметричної невизначеності $[1,2,3]$.

Розглядаються особливості ефективного функціонування ГТД при відповідних системах управління. Наприклад, на Одеському припортовому заводі експлуатуються установки 3 перевантаження і зберігання аміаку з газотурбінними приводами, яким необхідно, в деяких випадках, функціонувати певну кількість часу в неоптимальних режимах, які супроводжуються надмірним споживанням газу або підвищеною потужністю споживання системи охолодження аміаку в конденсато- 
$\operatorname{pax}[4]$. Так, в роботі [4] розглядається оцінка ефективності функціонування турбокомпресорної установки з перевантаження аміаку на основі відхилення від оптимального співвідношення технологічних параметрів. Аналогічним чином можна виділити оптимальне співвідношення технологічних параметрів і для газотурбінного двигуна, в схему якого також входить турбокомпресор динамічного принципу дії. Дане оптимальне співвідношення технологічних параметрів визначає ефективний режим функціонування двигуна, пов'язаний з найменшим споживанням газу (палива), або 3 підвищеною вірогідністю безаварійної роботи. Також відхилення від оптимального співвідношення параметрів може бути використано в схемі системи автоматичного управління для реалізації принципу координації - узгодження перехідних процесів [5 - 7].

Автоматичні системи координуючого керування дозволяють узгодити відповідні перехідні процеси і можуть забезпечити ряд позитивних особливостей при функціонуванні об'єкта управління. В результаті проведених досліджень, відображених в роботах [8], був зроблений висновок, що додатковий захист від виникнення помпажу компресора може забезпечити автоматична система координуючого управління, так як головне завдання даної системи - утримати робочу точку турбокомпресора на цільовому різноманітті, досить віддаленому від кордону помпажу. Це також актуально може бути і для ГТД, в яких помпаж може виникнути при непередбачених ситуаціях, наприклад при попаданні в двигун сторонніх предметів, струменю гарячих газів, присутності вітру при запуску двигуна і т.д. [9].

\section{Актуальність роботи}

При розробці інформаційної системи, що визначає енергоефективність функціонування установки за відхиленням від співвідношення параметрів, необхідна модель ГТД характеризується достатньою кількістю змінних. Дана модель дозволяє підтвердити достовірність інформації щодо аналізу енергоефективності функціонування установки згідно адекватності даних моделі ГТД. Актуальність розробки відповідної моделі обумовлена не тільки необхідністю оцінки енергоефективності ГТД, але також можливістю побудови певної координувальної системи автоматичного управління, що використовує відхилення від співвідношення змінних при регулюванні технологічних параметрів ГТД.

Нелінійна динамічна модель авіаційного ГТД досить складною, в зв'язку з цим в деяких роботах iii спрощують і представляють у вигляді системи лінеаризованих (стаціонарних) диференціальних рівнянь [10]. Для справжнього випадку при аналізі оцінки енергоефективності функціонування ГТД дана спрощена модель недостатня. Необхідна поелементна (модульна) математична модель, що представляє достатній набір змінних - параметрів ГТД, які взаємопов'язані в рамках елементів математичної моделі [11].

Розроблені спеціалізовані системи імітаційного моделювання роботи авіаційних ГТД на сталих і несталих режимах роботи дають можливість відобразити досить якісно моделювання перехідних процесів [12]. Однак при синтезі систем з нетрадиційною метою управління необхідно адаптувати модель ГТД під широко відому програму моделювання MATLAB $\backslash$ Simulink, тим самим представити модель відповідними засобами програми з можливістю коригування параметрів моделі в широкому діапазоні. Таким чином, в даній роботі представлена розробка елементної моделі ГТД засобами середовища MATLAB Simulink як результат коригування моделі статичних режимів роботи компресора динамічного принципу дії, представленого набором блоків look-up-table [13].

\section{Мета і завдання роботи}

Метою роботи є підвищення ефективності функціонування ГТД шляхом використання координувальної системи автоматичного управління.

Для досягнення поставленої мети необхідно розробити модель ГТД на базі моделі статичних режимів роботи компресора динамічного принципу дії, що реалізована засобами MATLAB । Simulink.

\section{2 Визначення структурних схем моделі гТД}

При оцінюванні ефективності функціонування ГТД і для забезпечення енергоефективного управління необхідно мати значення різноманітних технологічних параметрів, що мають місце в різних точках двигуна. При цьому можна виділити оптимальне співвідношення технологічних параметрів і відповідне відхилення від цього співвідношення $\varphi$ як показник ефективності функціонування установки (рисунок 1) [4].

Також відхилення від оптимального співвідношення технологічних параметрів $\varphi$ можна використовувати при реалізації координувального управління для забезпечення енергоефективних режимів функціонування і антипомпажного захисту ГТД $[5,7]$. Як показано на рисунку 1 , було встановлено, що для визначення відхилення від оптимального співвідношення технологічних параметрів необхідно знати температуру газу на вихлопі $T_{G l}$, витрату палива $G_{T}$ і кут установки направляючих лопаток компресора $\alpha_{v}$, а також тиск після компресора $P_{k}$ і швидкість обертання валу $n_{V}$. Значення формованого параметра $\varphi$ безпосере- 
дньо вказує режим функціонування ГТД згідно 3 виділеними обмеженням, що накладається на даний параметр $\varphi$. При синтезі математичної моделі ГТД як об'єкта управління виділені змінні $T_{G l}, G_{T}$,
$\alpha_{V}, P_{k}, n_{V}$, які безпосередньо пов'язані $з$ відхиленням $\varphi$, представляються в залежності від цілого ряду інших змінних, згідно структурнопараметричної схеми, відображеної на рисунку 2.

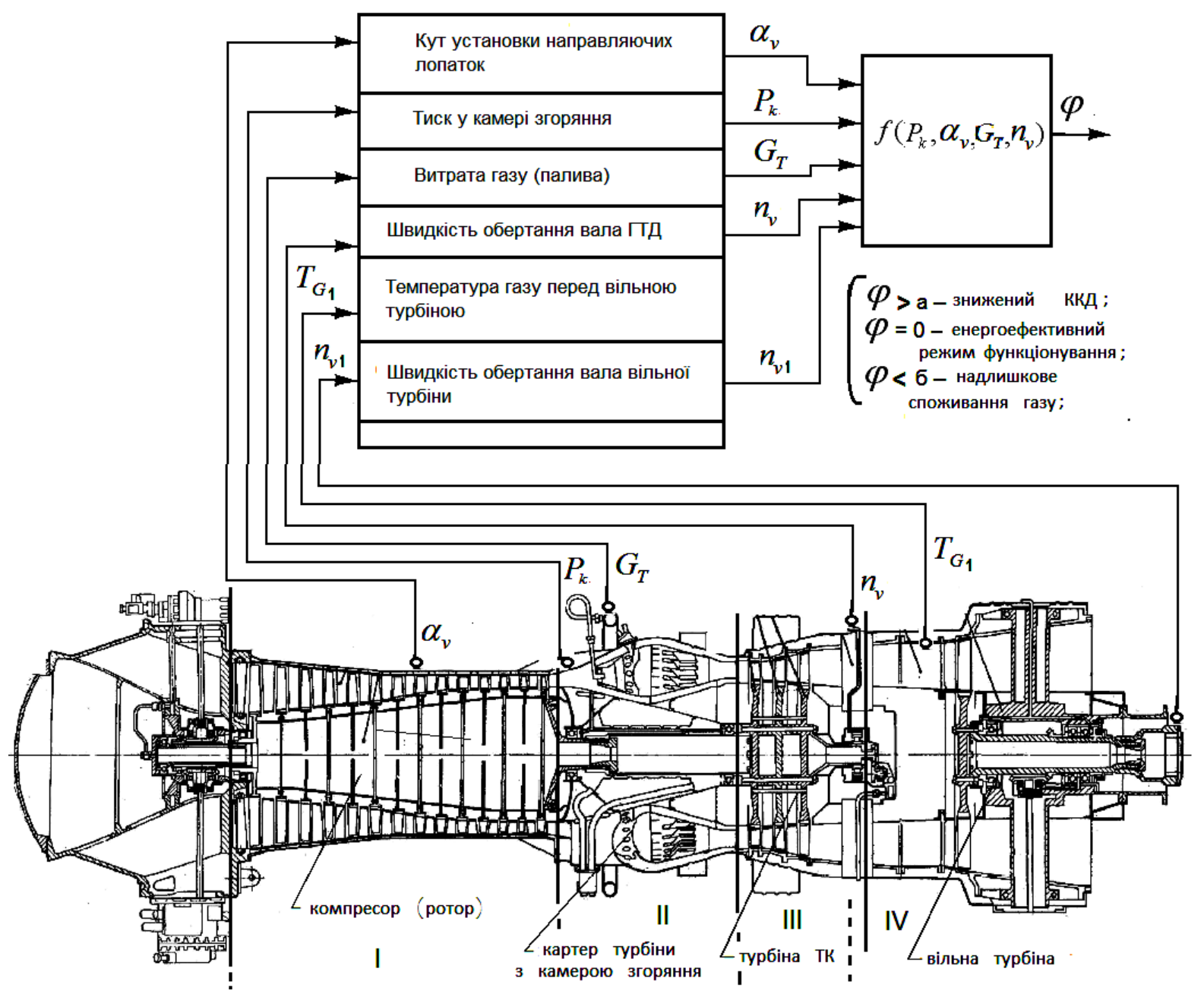

Рисунок 1 - Поперечний розріз газотурбінного двигуна з виділеними основними технологічними параметрами, необхідними для аналізу ефективності функціонування установки

При розробці математичної моделі, відповідно конструктивним особливостям (рисунок 1), ГТД можна розділити на турбокомпресор, камеру згоряння, турбіну і реактивне сопло. Виходячи 3 такого поділу, безпосередньо можна розглянути математичний опис окремих елементів ГТД, а потім зв'язати їх в єдину математичну схему, як показано на рисунку 2.

\section{1 Компресор}

Характеристики компресора зазвичай задаються графічно у вигляді залежностей: $\pi_{k}=f\left(G_{k}\right)$ $\eta=f\left(G_{k}\right)$, де, $\pi_{k}-$ ступінь підвищення тиску, $\eta-$ ККД компресора, $G_{k}$ продуктивність компресора. 3 даних характеристик компресора можна визначити статичні залежності:

$$
\begin{aligned}
& \pi_{k}=f\left(n_{v}, \alpha_{v}, w\right), \\
& G_{k}=f\left(n_{v}, \alpha_{v}, w\right),
\end{aligned}
$$

де $n_{v}$ - швидкість обертання валу компресора; $\alpha_{v}$ - кут установки направляючих лопаток; $w-$ вплив, який змінює характеристику мережі компpecopa.

Статичні залежності (1) і (2) при розробці моделі можна представити в табличному вигляді в елементах Lookup Table середовища моделювання MATLAB\Simulink.

Таким чином, в роботі [12] була представлена модель статичних режимів роботи компресора динамічного принципу дії, яку можливо перерахувати, і тим самим трансформувати в модель осьового компресора ГТД. Для цього необхідно розглянути модель, представлену в роботі [12] в діапазоні змі- 
ни кута установки лопаток компресора від $4,7^{\circ}$ до $5,5^{\circ}$, і при цьому необхідно скоригувати кінцеві значення ступеня підвищення тиску $\pi_{k}$ i продуктивності $G_{k}$. Слід зазначити, що осьовий компресор ГТД, наприклад НК-14Ст, що встановлюється на газоперекачувальних агрегатах, забезпечує ступінь підвищення тиску $\pi_{k}$ приблизно в 4 рази більше, ніж компресор, що представлений в роботі [12]. Якщо врахувати, що компресор проектується під конкретний агент або середу стиснення, то форму характеристики компресора також слід скори гувати. На рисунку 3 показані скориговані залежності, що представлені в роботі [12], які відображають форму характеристик компресора ГТД. Значення, що представлені в таблицях n-D Lookup Table3 1 i n-D Lookup Table3 2, істотно не відрізняються від значень, представлених в роботі [12], однак несуттєва корекція значень при $G_{m W}=2,5 \%$ та при $G_{m W}=10,75 \%$ істотно впливає на форму характеристик компресора. Відповідно були скориговані кінцеві значення ступеня підвищення тиску $\pi_{k}$ i продуктивності $G_{k}$, як показано на рисунку 4, згідно з характеристиками авіаційного ГТД.

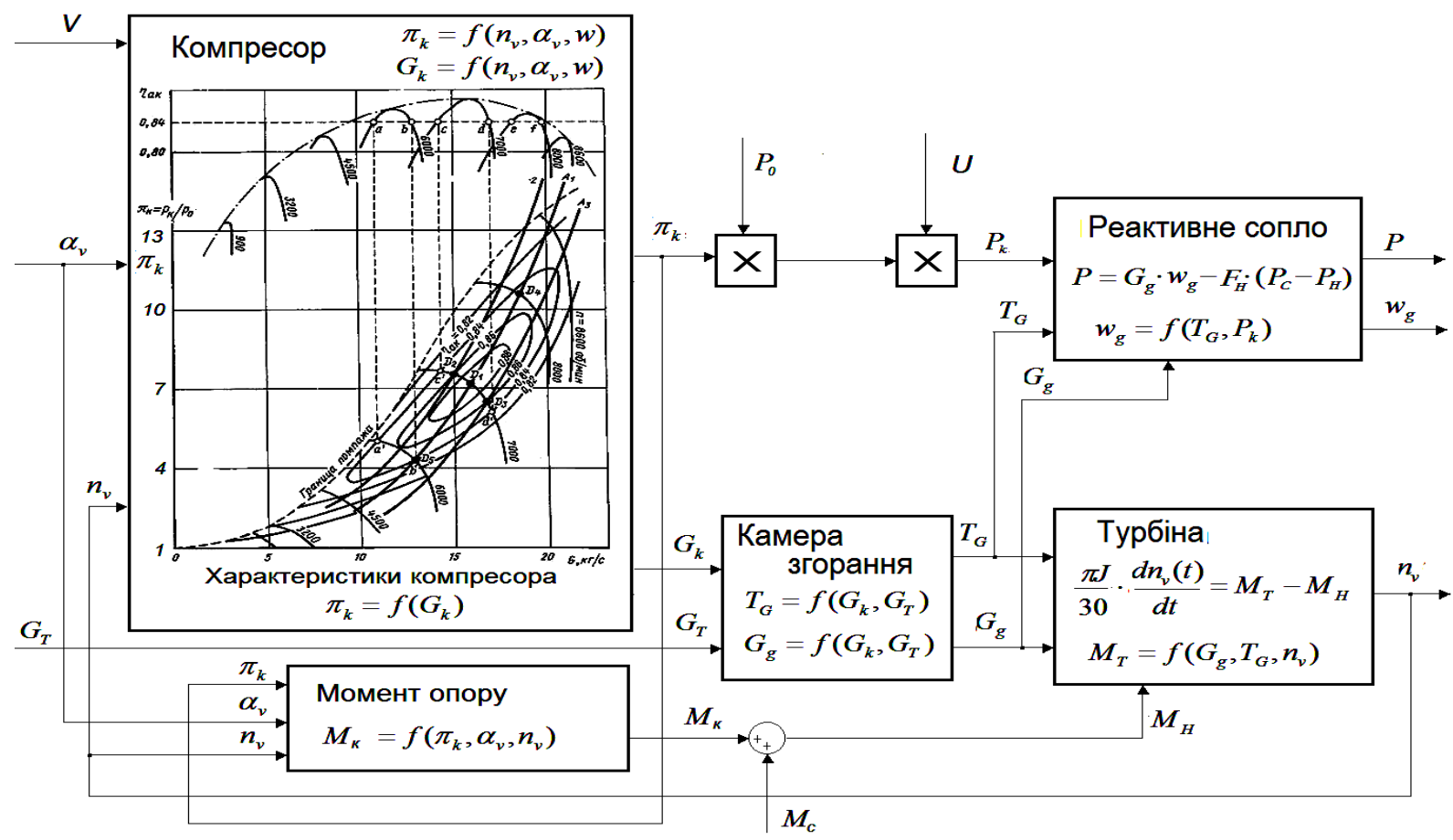

Рисунок 2 - Структурно-параметрична схема газотурбінного двигуна

\begin{tabular}{|c|c|r|r|r|r|}
\multicolumn{2}{|c|}{ Breakpoints } & \multicolumn{2}{|c|}{ Column } & (1) & \multicolumn{2}{c|}{ (3) } \\
\cline { 2 - 5 } Row & $\mathbf{2 . 5}$ & $\mathbf{4 . 7}$ & $\mathbf{8 . 5}$ & \multicolumn{1}{|c|}{$\mathbf{1 6 . 5}$} \\
\hline$(1)$ & $\mathbf{1 0 . 7 5}$ & 0 & 20 & 20 \\
\hline$(2)$ & $\mathbf{1 2 . 5}$ & 0 & 24.5 & 30 \\
\hline$(3)$ & $\mathbf{2 0}$ & 0 & 25 & 34.25 \\
\hline$(4)$ & $\mathbf{2 5}$ & 0 & 28.25 & 44 \\
\hline$(5)$ & $\mathbf{3 7 . 5}$ & 0 & 35.5 & 64.8 \\
\hline$(6)$ & $\mathbf{6 2 . 5}$ & 0 & 42.35 & 76.5 \\
\hline$(7)$ & $\mathbf{8 7 . 5}$ & 0 & 44.7 & 92.4 \\
\hline$(8)$ & $\mathbf{1 0 0}$ & 0 & 45 & 98.5 \\
\hline$(9)$ & & 0 & 45 & 99 \\
\hline
\end{tabular}

Data Type: Row: double - Column: double - Table: double -

Dimension Selector:

\begin{tabular}{|c|r|r|r|}
\hline Dimension size & 9 & 3 & 2 \\
\hline Select 2-D slice & All & All & 1 \\
\hline
\end{tabular}

n-D Lookup Table3 1

\begin{tabular}{|c|c|c|c|c|}
\hline Breakpoints & Column & (1) & (2) & (3) \\
\hline Row & $m$ & 4.7 & 8.5 & 16.5 \\
\hline (1) & 2.5 & 0 & 20 & 20 \\
\hline (2) & 10.75 & 0 & 24.5 & 40 \\
\hline (3) & 12.5 & 0 & 35 & 54.25 \\
\hline (4) & 20 & 0 & 41.25 & 78 \\
\hline (5) & 25 & 0 & 42.5 & 92.8 \\
\hline (6) & 37.5 & 0 & 43.75 & 96.5 \\
\hline (7) & 62.5 & 0 & 44.7 & 98.4 \\
\hline (8) & 87.5 & 0 & 45 & 99 \\
\hline (9) & 100 & 0 & 45 & 99 \\
\hline
\end{tabular}

Data Type: Row: double - Column: double - Table: double -

Dime

\begin{tabular}{c|r|r|r|r|}
\hline Dimension Selector: & \multicolumn{3}{|c|}{3} & 2 \\
\hline Dimension size & 9 & 3 & 2 \\
\hline Select 2-D slice & All & All & - & 2 \\
\hline
\end{tabular}

n-D Lookup Table3 2

Рисунок 3 - Залежності між впливом $G_{m w}$, що змінює характеристику мережі компресора, кутом установки направляючих лопаток $\alpha_{д}\left(4,7^{0} ; 8,5^{0} ; 16,5^{0}\right)$ і збільшенням продуктивності $G_{A}$ при швидкості обертання валу $n_{v}=80 \%$ (n-D Lookup Table3 1) і при $n_{v}=100 \%$ (n-D Lookup Table3 2) 
Tаблиця 1 - Залежності температури $T_{G}$ і витрати газу на вихлопі $G_{g}$ при різних швидкостях обертання валу $n_{v}$ i моментах опору $M_{C}$

\begin{tabular}{|c|c|c|c|c|c|c|}
\hline $\begin{array}{l}\text { № } \\
\text { 3/п }\end{array}$ & $\begin{array}{c}\text { Швидкість обе- } \\
\text { ртання валу } n_{v}, \\
\text { об/хв }\end{array}$ & $\begin{array}{c}\text { Навантаження } \\
\text { на валу, } \\
\%\end{array}$ & $\begin{array}{c}\text { Витрата } \\
\text { паливного газу, } \\
\mathbf{m}^{3} / \mathbf{M}\end{array}$ & $\begin{array}{c}\text { Продуктивність } \\
\text { компресора, } \\
\%\end{array}$ & $\begin{array}{c}\text { Витрата газу на } \\
\text { вихлопі, } \\
\text { кг/c }\end{array}$ & $\begin{array}{c}\text { Температура } \\
\text { газу на вихлопі } \\
T_{G},{ }^{0} \mathrm{~K}\end{array}$ \\
\hline 1 & 8200 & 90 & 4294 & 95,41 & 38,08 & 750 \\
\hline 2 & 8150 & 58 & 3219 & 76,2 & 29,5 & 730 \\
\hline
\end{tabular}

\section{2 Камера згоряння}

Температура $T_{G}$ і витрата газу $G_{g}$ на виході 3 камери згоряння визначаються з рівнянь теплового і матеріального балансу, виходячи з яких представляються залежності:

$$
\begin{aligned}
T_{G} & =f\left(G_{k}, G_{T}\right), \\
G_{g} & =f\left(G_{k}, G_{T}\right),
\end{aligned}
$$

де, $G_{k}$ - продуктивність компресора; $G_{T}$ - витрата палива.

\section{3 Турбина}

Витрата газу через турбіну і їі ККД можна визначити за розрахунковими або експериментальними характеристиками, однак, крім цього, в даній моделі необхідно виділити швидкість обертання валу ГТД. Для цього необхідно представити відповідне рівняння руху ГТД.

Рівняння руху, яке описує нестаціонарний режим роботи турбіни, наступне [14]:

$$
(\pi J / 30) \cdot d n_{v}(t) / d t=M_{T}-M_{C}
$$

де $M_{T}=f\left(G_{g}, T_{G}, n_{v}\right)-$ момент, який розвиває турбіна н·м; $M_{C}=f\left(\pi_{k}, \alpha_{v}, n_{v}\right)+M_{H}-$ момент опору; $T_{G}-$ температура газу перед турбіною; $G_{g}$ - витрата газу на вихлопі; $n_{v}$ - швидкість обертання валу; $\alpha_{v}$ кут установки направляючих лопаток компресора; $\pi_{k}$ - ступінь підвищення тиску.

Залежності температури і витрата газу на вихлопі $G_{g}$ при різних швидкостях обертання валу $n_{v}$ i моментах опору також були представлені в табличному вигляді в блоках Look-up table згідно 3 прийнятими даними, частково наведеними в таблиці 1.

\section{4 Реактивне сопло}

Реактивне сопло можна охарактеризувати рівняннями для розрахунків сили реактивної тяги $\mathrm{i}$ швидкості витікання.

Сила реактивної тяги двигуна:

$$
P=G_{g} \cdot w_{g}-F_{c} \cdot\left(P_{c}-P_{H}\right)
$$

при цьому, швидкість витікання газу

$$
w_{g}=f\left(T_{G}, P_{k}\right)
$$

де, $T_{G}, P_{k}$ - температура і тиск газу в камері згоряння; $F_{c}$ - площа зрізу сопла; $P_{c}$ - тиск на зрізі сопла; $P_{H}-$ тиск навколишнього середовища.

Як показано на рисунку 4, виходячи 3 вищенаведеного поелементного математичного опису ГТД, можна сформувати схему моделі в середовищі MATLABISimulink. Всі дані про статичниі режими роботи двигуна відображені в блоках Lookup Table, а значення змінних відображаються в блоках Display.

\section{5 Аналіз результатів моделювання ГТД}

В результаті моделювання ГТД в середовищі Matlab/Simulink були отримані статичні і динамічні характеристики, на підставі яких можна зробити висновок про адекватність моделі для дослідження систем координувального управління.

На рисунку 5а представлені характеристики турбокомпресора, що працює на R22, при різних швидкостях обертання валу $\boldsymbol{n}_{\boldsymbol{v}}$ і при куті установки лопаток дифузора $\alpha_{D}=4,7^{\circ}$. На рисунку $5 \mathrm{~b}$ представлено характеристики осьового компресора ГТД, модель якого була отримана на основі перетворення моделі компресора 3 характеристиками, представленими на рисунку 5 а.

Як видно 3 рисунка 5, характеристики осьового компресора ГТД при різних швидкостях обертання валу значно відрізняються за ступенем підвищення тиску $\pi$ від первісних характеристик компресора, представлених на рисунку 5а. При цьому отримані статичні характеристики моделі осьового компресора істотно не відрізняються за ступенем підвищення тиску i, відповідно, за формою від експериментальних характеристик.

Також в результаті моделювання були отримані перехідні характеристики роботи ГТД (рисунок 6). 3 динамічних характеристик видно, що перехідні процеси носять аперіодичний характер, що відповідає нефорсованим режимам роботи ГТД, при цьому помітний прояв нелінійності моделі ГТД, що пов'язаний з несуттєвою різною інерційністю двигуна при розгоні на різні швидкості обертання валу. 


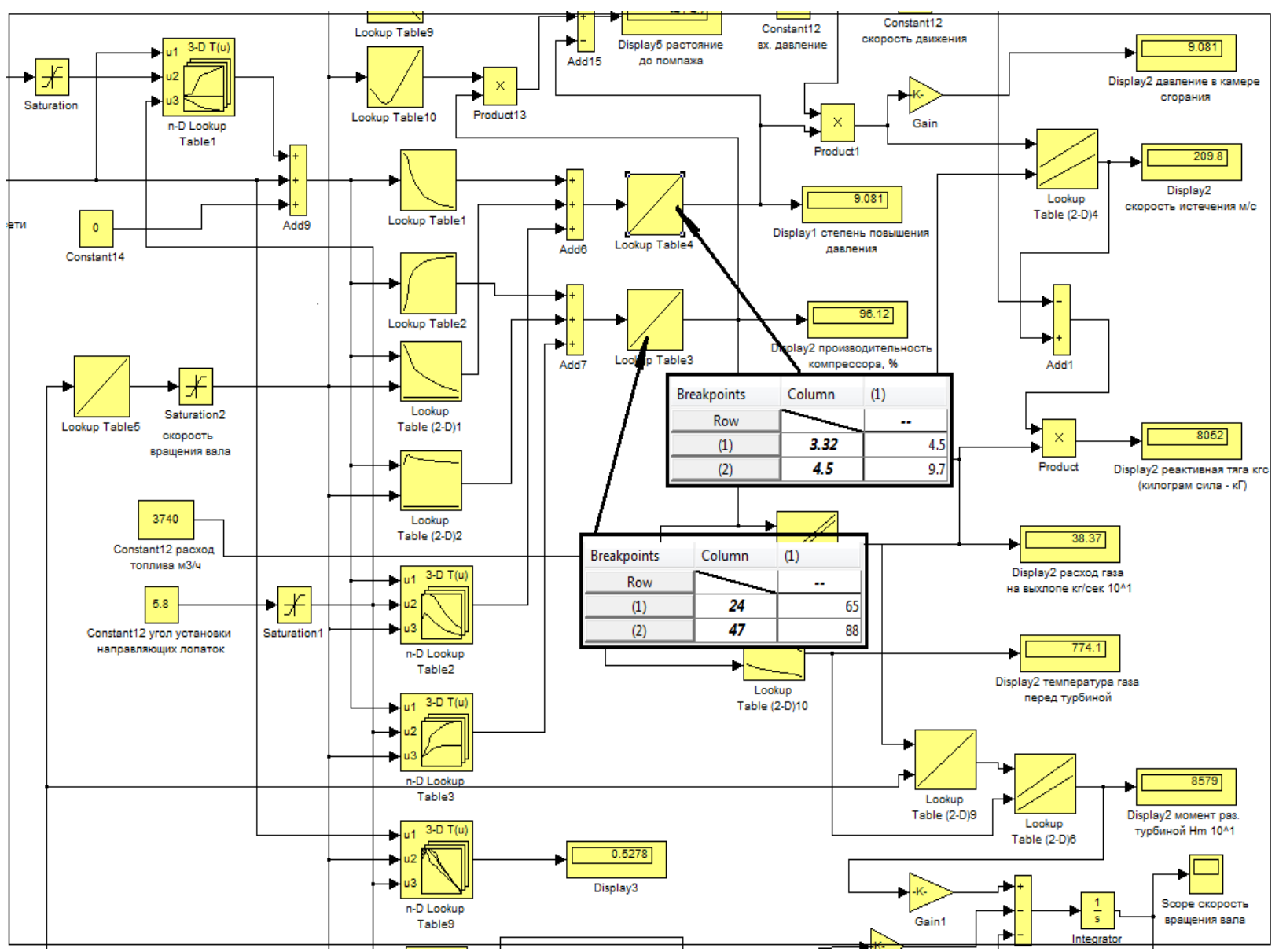

Рисунок 4 - Схема моделі газотурбінного двигуна, реалізована в середовищі Matlab Simulink (жирними стрілками вказані блоки корекції моделі турбокомпресора)

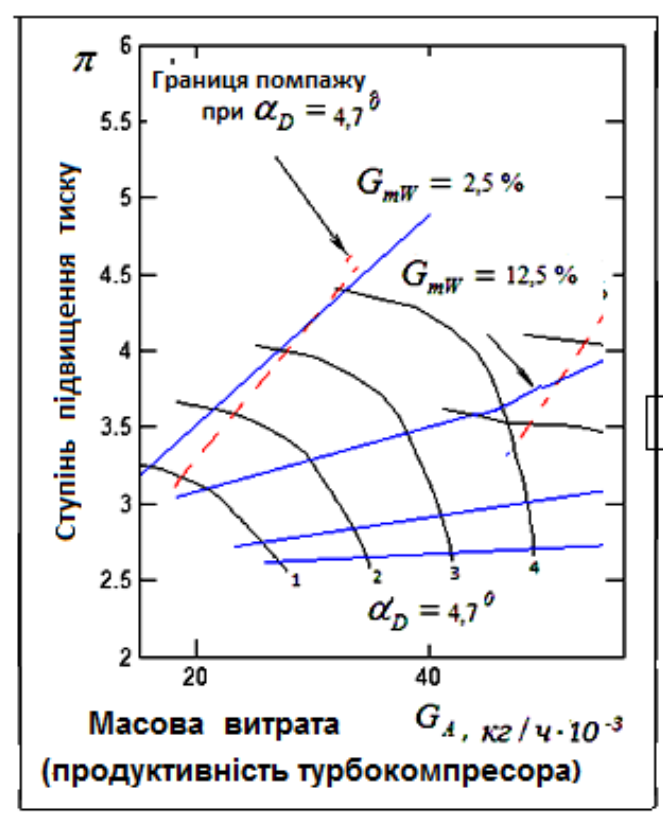

a)

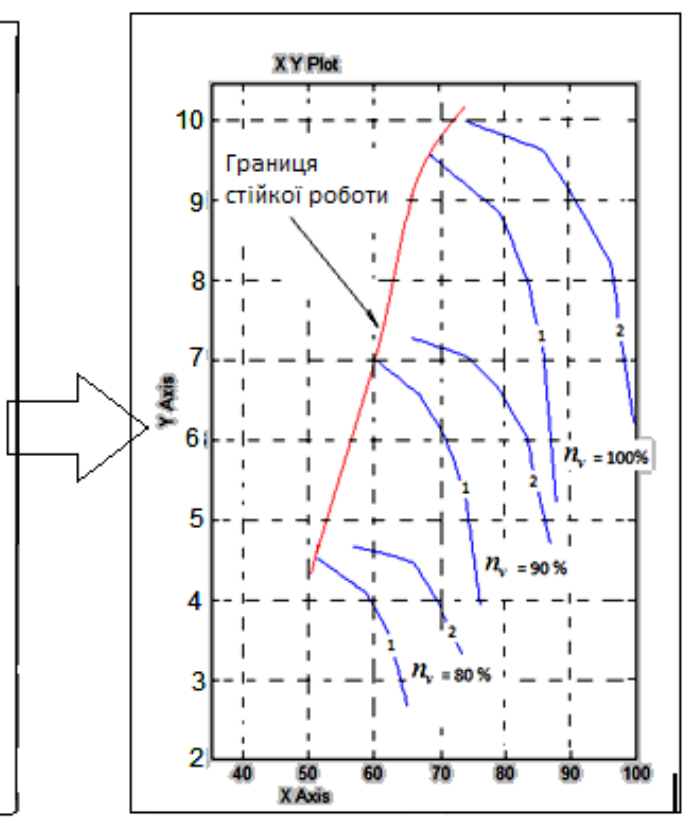

b)

Рисунок 5 - Характеристики компресора, що працює на агенті R22, і характеристики компресора газотурбінного двигуна 


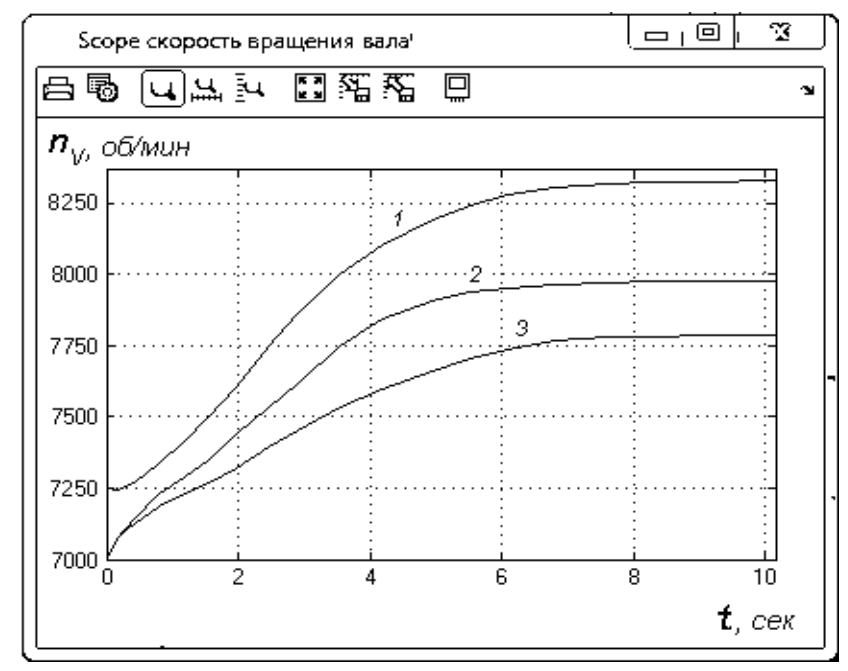

Рисунок 6 - Перехідні характеристики ГТД за швидкістю обертання вала, отримані в результаті моделювання в середовищі MATLAB / Simulink

\section{3 Висновки}

В результаті роботи була розроблена модель ГТД як об'єкта управління з формуванням відхилення від оптимального співвідношення значень технологічних параметрів як показника ефективності функціонування ГТД. Дана модель дає можливість визначити адекватність оцінки ефективності функціонування ГТД, а також виконати синтез різних систем управління, в тому числі координувальних, та систем антипомпажного захисту.

Розроблена в цьому випадку поелементна модель ГТД засобами середовища MATLAB Simulink на базі моделі статичних режимів роботи компресора динамічного принципу дії може бути скоригована відповідно до експериментальних даних і характеристик даного двигуна. I таким же чином можливо виконати синтез відповідних систем управління.

Подальший можливий розвиток моделі ГТД безпосередньо має здійснюватися в рамках синтезу певної системи автоматичного управління або системи антипомпажного захисту.

\section{Література}

1. Ильясов, Б. Г. Применение логического регулятора для управления авиационным газотурбинным двигателем [Текст] / Б.Г. Ильясов, Г.А. Саитова, И.И. Сабитов //Вестник Уфимского государственного авиационного технического университета. - 2015. - Т. 19. - №. 4 (70). - С. 132-137.

2. Петунин, В. И. Метод построения адаптивных логико-динамических систем автоматического управления с селекторами [Текст] / В. И. Петунин, А. И. Фрид // Известия высших учебных за- ведений. Приборостроение. - 2011. - Т. 54. - №. 5. - C. 49-56.

3. Павлюк, Е. В. Синтез контура управления частотой вращения свободной турбины вспомогательной силовой установки [Текст] / Е. В. Павлюк, С. В. Епифанов, С. И. Суховей //Авиационнокосмическая техника и технология. -2004 . - №. 8. - C. 110-113.

4. Гурский, А. А. Невязка по соотношению параметров в системе управления как показатель функционирования турбокомпрессорной установки [Текст] / А. А. Гурский, В. А. Денисенко, А. Е. Гончаренко //Холодильная техника и технология. - 2014. - T. 50. - №. 4. - С. 58-64.

5. Филимонов, А. Б. О проблематике синтеза координирующих систем автоматического управления [Текст] / А. Б. Филимонов, Н. Б. Филимонов // Известия Южного федерального университета. Технические науки. - 2012. - Т. 128. - №. 3.- С. 172-180.

6. Бойчук Л. М. Синтез координирующих систем автоматического управления / Л.М. Бойчук. - М.: «Энергоатомиздат», 1991. - $160 \mathrm{c.}$

7. Гурский, А. А., Система управления, обеспечивающая энергоэффективное функционирование холодильной турбокомпрессорной установки [Текст] / А. А. Гурский, В. А. Денисенко, А. Е. Гончаренко //Автоматизация технологических и бизнес-процессов. - 2015. - Т. 21. - №. 21.- С. $62-$ 67.

8. Гурський О.О. Автоматизація холодильної турбокомпресорної установки на базі системи координуючого керування : автореф. дис. на здобуття наукового ступеня канд. тех. наук : спец.05.13.07 «Автоматизація процесів керування» / О.О. Гурський. - Одеса, 2012. - 20 с.

9. Токарев, В. П. Система диагностирования предпомпажного состояния газотурбинного двигателя [Текст] / В. П. Токарев, Д. Д. Кудашов //Вестник Уфимского государственного авиационного технического университета. - 2014. - Т. 18. №. 1 (62). - С. 73-78.

10. Ахмедзянов, Д. А. Расчетное исследование динамической характеристики одновального турбореактивного двигателя [Текст] / Д. А. Ахмедзянов, и др. //Вестник Уфимского государственного авиационного технического университета. - 2011. - T. 15 . - №. 1 (41). - C. 15-25.

11. Муравченко, О. Ф. Поэлементная математическая модель турбовинтовентиляторного двигателя Д-27 [Текст] / О. Ф. Муравченко, А. Н. Хусточка //Авіаційно-космічна техніка і технологія. 2003. - №. 6. - С. 75-78.

12. Кривошеев, И. А. Имитационное моделирование работы авиационных ГТД с элементами систем управления [Текст] / И. А. Кривошеев, Д. А. 
Ахмедзянов, А. Е. Кишалов //Вестник Уфимского государственного авиационного технического университета. - 2008. - Т. 11. - №. 2. - С. 3-11.

13. Гурский, А.А. Моделирование статических режимов работы холодильного центробежного компрессора / А.А. Гурский, В.А. Денисенко, А.Е. Гончаренко // Холодильная техника и технология - 2015 - №6 - С. 83-90.
14. Madarász L., Andoga R., Fozo L. Intelligent technologies in modeling and control of turbojet engines //New Trends in Technologies: Control, Management, Computational Intelligence and Network Systems. - InTech, 2010.

Отримана в редакції 25.02.2019, прийнята до друку 02.04.2019

\title{
The development of the turbojet model on the basis of data received as a result of the recalculation of the turbo compressor characteristics
}

\author{
A.A. Gursky, A.E. Goncharenko, S.M. Dubna
}

Odessa national academy of food technologies, 112 Kanatna str, Odesa, 65039, Ukraine

$\triangle$ e-mail: dubna_s@ukr.net

\begin{abstract}
The article presents a model of a turbojet. The model was developed by means of programming environment MATLAB\Simulink. Also the article presents an exact method of this model development. The aim of the study is the increase of effective functioning of the turbojet by means of the using of the coordinating system. The relevance of developing a relevant model is related to the need to assess the energy efficiency of the gas turbine engine, and also the possibility of building a specific coordinating automatic control system. In order to achieve this aim we need to develop the turbojet model based on the compressor model. The paper presents the element model development of the turbojet. This model is designed to synthesize various automatic control systems providing the coordination of transients response during the regulation. The parametric scheme of the turbojet is presented with a description of its individual elements. We have presented the principle of converting the initial compressor model for the appropriate model of the turbojet. The initial compressor model is considered as a base for development of various turbojet models. Presented turbojets are used in gas pumping plant. In particular cases the presented turbojet is used on chemical factory, which deals with ammonia transshipment. Transshipment and storage of ammonia is provided by powerful turbocompressor units with gas turbine engine. Those units must functionate without breakdowns and in energy efficient mode. To analyze energy efficiency we must have unit's dynamic model. The results of modeling are shown in the final part of the article. These are the static characteristics of the turbojet and transient response of the rotational speed of the turbine shaft. The simulation results are analyzed in this scientific work. The static characteristics of the model of the initial compressor and the compressor of the turbojet are compared.
\end{abstract}

Keywords: Turbojet; Mathematical model; Static characteristics; Combustion chamber; Turbocompressor.

\section{References}

1. Ilyasov, B. G., Saitova, G. A., Sabitov, I. I. (2015) Primenenie logicheskogo regulyatora dlya upravleniya aviacionnym gazoturbinnym dvigatelem [The application of logical controller for aircraft gas turbine engine control]. Vestnik UGATU, no. 4(70), 132-137 (in Russian)

2. Petunin, V.I., Frid, A.I. (2011) Metod postroeniya adaptivnyh logiko-dinamicheskih sistem avtomaticheskogo upravleniya s selektorami [Method of construction of adaptive automatic control logicdynamic system with selector]. Journal of instrument engineering, no. 5, 49-56 (in Russian)
3. Pavlyuk, E.V., Epifanov, S. V., Suhovei S. I. (2004) Sintez kontura upravleniya chastotoj vrashcheniya svobodnoj turbiny vspomogatel'noj silovoj ustanovki [Synthesis of the speed control circuit for the spare turbine of the auxiliary power plant]. Aerospace technic and technology, no. 8, 110 113 (in Russian)

4. Gurskiy, A., Denisenko, V., Goncharenko, A. (2014) Nevyazka po sootnosheniyu parametrov v sisteme upravleniya kak pokazatel' funkcionirovaniya turbokompressornoj ustanovki [Deficiency on the ratio parameters in a control system as a parameter of turbo compressor plant functioning] Refrigeration Engineering and Technology, no. 4, 58-64 (in Russian) 
5. Filimonov, A. B., Filimonov N. B. (2012) Concerning the problems of synthesis of coordinated systems of automatic control [O problematike sinteza koordiniruyuschih sistem avtomaticheskogo upravleniya] Izvestiya SfedU, Engineering sciences, no. 3, 172-180 (in Russian)

6. Boychuk, L. M. (1991) Synthesis of coordinated systems of automatic control [Sintez koordinirujushih sistem avtomaticheskogo upravlenija] Moscow, Energoatomizdat, 160 p. (in Russian)

7. Gurskiy, A. A., Goncharenko, A. E., Denisenko, A.V. (2015) Sistema upravleniya, obespechivayushchaya ehnergoehffektivnoe funkcionirovanie holodil'noj turbokompressornoj ustanovki [The control system providing the efficient functioning of the refrigeration plant] Automation of technological and business processes, no. 21, 62-67 (in Russian)

8. Gurskiy, A.A. (2012) Avtomatizaciya holodil'noï turbokompresornoï ustanovki na bazi sistemi koordinuyuchogo keruvannya [Automation of turbo compressors plant of refrigerating based on the coordination control systems]. Extended abstract of candidate's thesis. Odessa (in Ukrainian).

9. Tokarev, V.P., Kudashov, D.D. (2014) Sistema diagnostirovaniya predpompazhnogo sostoyaniya gazoturbinnogo dvigatelya [Before compressor stall condition of GTE condition diagnostic system]. Vestnik UGATU, no. 1, 73-78 (in Russian)

10. Akhmedzyanov, D.A., Akhmetov, Yu.M., Kozlovskaya, A.B., Mikhailov, A.E (2011)
Raschetnoe issledovanie dinamicheskoj harakteristiki odnoval'nogo turboreaktivnogo dvigatelya [Rated research of response characteristic of the turbojet]. Vestnik UGATU, no. 1, 15-25 (in Russian)

11. Muravchenko, O.F., Khustochka, A.N. (2003)

Poehlementnaya matematicheskaya model' turbovintoventilyatornogo dvigatelya D-27 [The elemental mathematical model of the turbo jet D-27]. Aerospace technic and technology, no. 6, 75-78 (in Russian)

12. Krivosheev, I.A., Akhmedzyanov, D.A., Kishalov, A.E. (2008) Imitacionnoe modelirovanie raboty aviacionnyh GTD s ehlementami sistem upravleniya [The imitation modeling of air turbine engines with control system elements]. Vestnik UGATU, no. 2, 311 (in Russian)

13. Gurskiy, A., Denisenko, V., Goncharenko, A. (2015) Modelirovanie staticheskih rezhimov raboty holodil'nogo centrobezhnogo kompressora [Modelling of static modelling of static modes function of the refrigeration centrifugal compressor] Refrigeration Engineering and Technology, no. 6, 83-90 (in Russian)

14. Madarász, L., Andoga, R., Fozo, L. (2010) Intelligent technologies in modeling and control of turbojet engines. New Trends in Technologies: Control, Management, Computational Intelligence and Network Systems. InTech 2010. 